\title{
New interpretation of the provenance of crystalline material from Oligocene flysch deposits of the Skole Nappe, Poland: evidence from heavy minerals and clasts in the Nowy Borek section
}

\author{
Dorota Salata*, Alfred Uchman \\ Jagiellonian University, Faculty of Geography and Geology, Institute of Geological Sciences, Gronostajowa 3a, \\ 30-387 Kraków, Poland \\ *corresponding author, e-mail: dorota.salata@uj.edu.pl
}

\begin{abstract}
The Futoma Member (Oligocene, Rupelian) of the Menilite Formation is present only in the northern part of the Skole Nappe. Some diatomitic layers of this member in the Nowy Borek section contain coarse-grained detrital material composed of a variety of metamorphic, volcanic and sedimentary rock fragments. The material derives from primary and secondary sources. Most abundant are debris of metamorphic rocks, mostly gneisses and mica schists. The metamorphic origin of these rocks is confirmed by the composition of heavy mineral assemblages and garnet chemistry. These rocks could have been transported from a local source located close to the margin of the Skole Basin or within that basin. The volcanic rocks reflect Paleogene volcanic activity that was widespread in the Carpathian region. Cherts, which could have been subjected to synsedimentary erosion, may have been derived from the older portions of the same formation.
\end{abstract}

Key words: detrital material, provenance, Futoma Member, Carpathians

\section{Introduction}

The origin of sedimentary material in the thick series that fill flysch basins in the Polish Carpathians is still not fully understood. In Poland, the basic methods of research has included, first and foremost, determination of directions of sediment transportation or petrographic and heavy mineral studies (e.g., Wdowiarz, 1949; Bukowy, 1957; Kotlarczyk \& Śliwowa, 1963; Ślączka \& Unrug, 1966; Szczurowska, 1970, 1971, 1973; Kotlarczyk, 1976; Bromowicz, 1986; Skulich, 1986; Rajchel \& Myszkowska, 1998; Salata \& Uchman, 2012, 2013; Salata, 2013a, b, 2014). In the Polish Flysch Carpathians, directions of sedi- ment transportation generally have been recognised (e.g., Książkiewicz, 1962), but petrographic and especially heavy mineral investigations have been done only for some formations (e.g., Szczurowska, 1970, 1971, 1973; Grzebyk \& Leszczyński, 2006; Salata \& Uchman, 2012, 2013; Salata, 2013a, b, 2014; and references therein). In spite of all these research efforts, there are still unresolved issues concerning the palaeogeography and provenance of clastic material found in lithostratigraphic units in the Polish Flysch Carpathians.

For the Menilite Formation (Oligocene) of the Skole Nappe, directions of transportation were presented by Kotlarczyk \& Leśniak (1990) and heavy 
minerals from sandstone bodies were studied by Szczurowska (1970, 1971, 1973), Salata \& Uchman $(2012,2013)$ and Salata $(2013 a, b, 2014)$. Relatively less attention was paid to petrographic studies that focused on the origin of coarse-grained material (e.g., Kotlarczyk \& Śliwowa, 1963).

The petrography of pebble- and sand-fraction debris and heavy minerals from the Futoma Member at Nowy Borek (also Borek Nowy in the literature) are presented here. The debris in the Nowy Borek section differs from that of other localities, which may indicate that some source of crystalline rocks was still active during the Oligocene and that older rocks of the Skole Nappe successions were eroded. So far, this is the youngest occurrence of crystalline rock pebbles in the flysch formations of the Skole Nappe. A revision of previously published data (Kotlarczyk, 1985; Kotlarczyk \& Kacz- marska, 1987) and presentation of new results, which change the interpretation of the origin of the material studied and add new facts on dynamic sedimentation in the Skole Basin, are the main aims of the present paper.

\section{Geological setting}

The Menilite Formation (also known as the Menilite Beds) is a lithostratigraphic unit which is widespread in the Oligocene of the Flysch Carpathians. It is characterised by dark, commonly black or brown, deep-sea shales deposited periodically under anoxic conditions (see Kotlarczyk et al., 2006; Kotlarczyk \& Uchman, 2012 and references therein). In the Skole Basin, which was palaeogeographically situated between the European Platform in the north and the

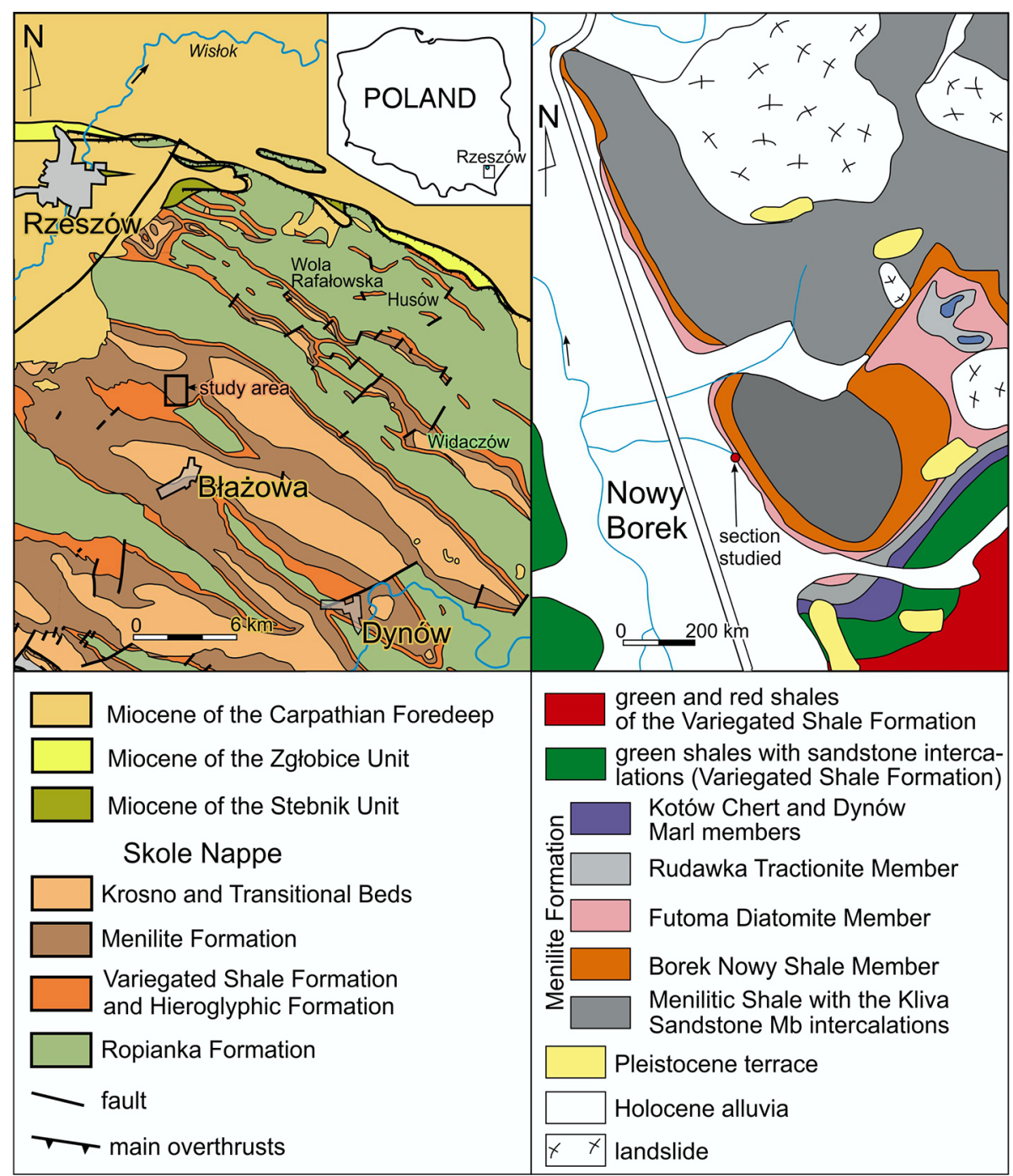

Fig. 1. Locality maps with indication of the Nowy Borek section (left-hand map modified from Kotlarczyk \& Leśniak, 1990; right-hand map modified from Kotlarczyk, 1985) 
Subsilesian (Węglówka) ridge and slope in the south and is at least about $150 \mathrm{~km}$ wide (Gągała et al., 2012), the Menilite Formation, followed by the Krosno Formation, form the highest part of the sedimentary succession (Fig. 1). The Menilite Formation is $400 \mathrm{~m}$ thick in the study area. It contains significant sandstone units distinguished at lithostratigraphic divisions (Fig. 2). However, the lithostratigraphic divisions are a matter of controversy (Malata, 1996, 2006). A simpler lithostratigraphic scheme for the Oligocene of the Skole Nappe, with a smaller number of subdivisions, was presented by Jankowski et al. (2012b, p. 96), but those authors failed to discuss this in the light of the more refined scheme proposed by Kotlarczyk et al. (2006). The latter is followed here.

The present study focuses on the Futoma Member, also referred to as the Futoma Diatomite Horizon (Kotlarczyk, 1982), Futoma Diatomite or Futoma Diatomite Member (Kotlarczyk, 1985; Kotlarczyk et al., 2006), which is Rupelian (nannoplankton NP23 Zone) in age. This unit is present only in the northern part of the Skole Basin where it is sandwiched between brown mudstone-sandstone deposits of the Rudawka Tractionite Member and brown shales of the Borek Member. The Futoma Member is up to 24 metres thick (10-15 $\mathrm{m}$ at the locality studied) and pinches out laterally. The outcrop studied at Nowy Borek near Rzeszów (outcrop no. 2 in Kotlarczyk, 1985; GPS co-ordinates $49^{\circ} 55.164^{\prime} \mathrm{N}, 2^{\circ} 05.357^{\prime} \mathrm{E}$ ) is a classic of the few outcrops of this member. It represents a 2.2-m-thick portion of the upper part of the member, which contains laminated diatomites, diatomaceous shales and mostly structureless, beige-coloured diatomite "mud flows" with exotic pebbles of "granite with pink feldspar" as determined by Kotlarczyk (1985, p. 106) (see Fig. 3). Kotlarczyk \& Kaczmarska (1987, p. 147) noted "granite granules and pebbles" and Kotlarczyk et al. (1991) referred to muscovite, debris of coal and molluscan shells. These deposits contain also a lot of gravel grains (up to 10.5 per cent) and can be considered as mud flow sediments with pebbles or locally as pebble mudstone, which were called also "diamictites" (Kotlarczyk et al., 1991, p. 21).

The Futoma Member was deposited in slope depressions between channels, which were pathways of sand deposition transported from the northwest. The deposition took place at a time of maximum

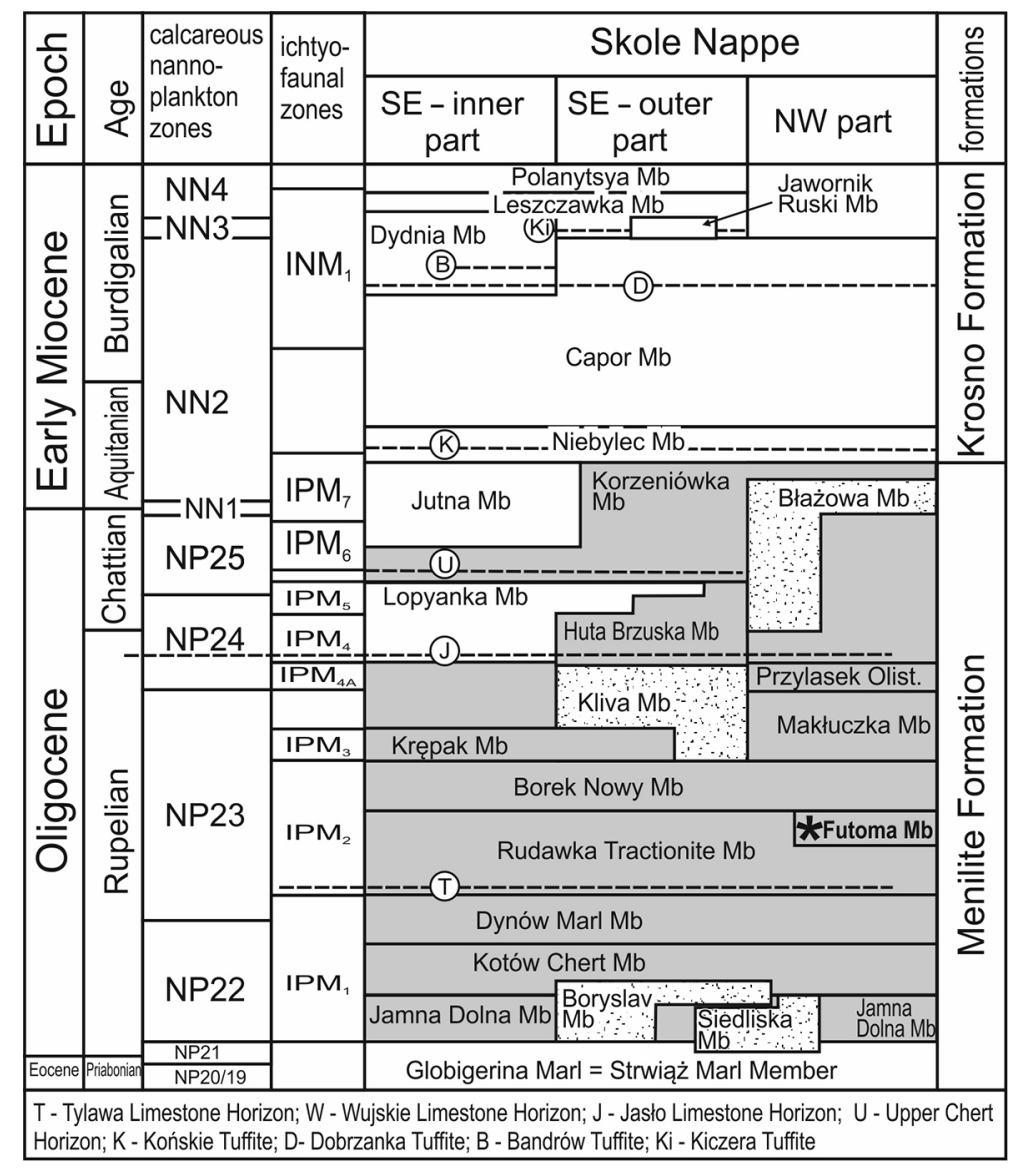

Fig. 2. Stratigraphic scheme of the Menilite Formation in the Skole Nappe (based on Kotlarczyk et al., 2006), with indication of the position of the Futoma Member section studied 


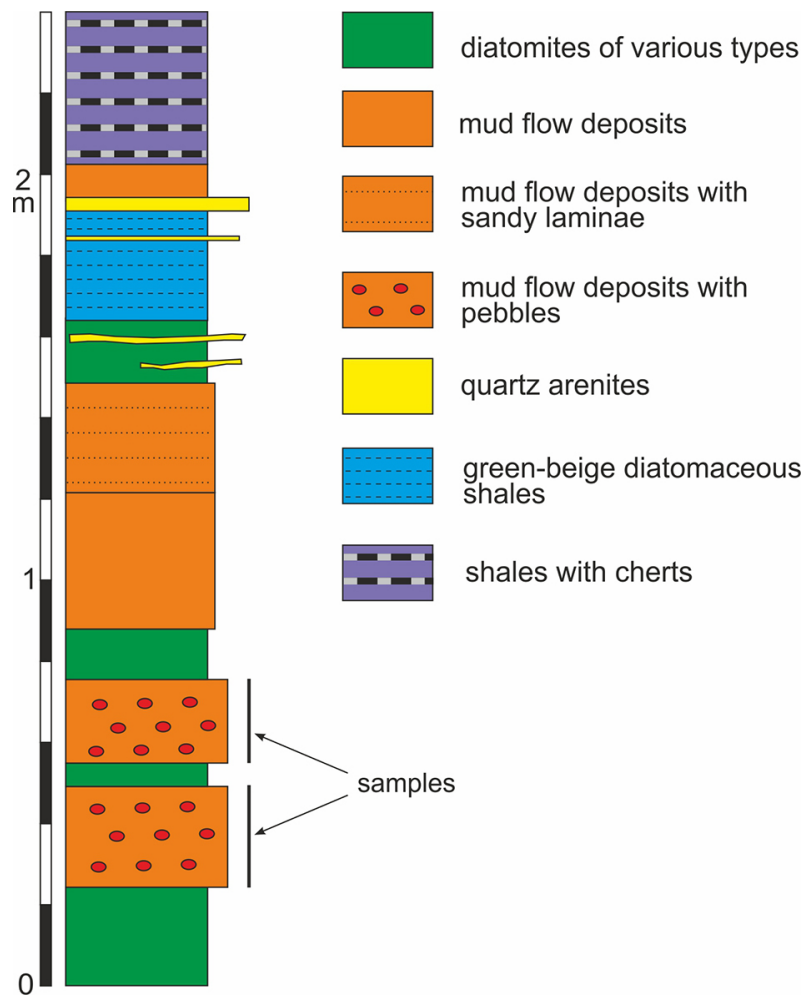

Fig. 3. Lithological column of the outcrop studied (based on Kotlarczyk, 1985, modified)

diastrophic quiescence, but deposition of the diatomaceous material was disturbed by several mud flows (Kotlarczyk \& Leśniak, 1990). The depositional system was determined as interchannel fans (Kotlarczyk, 1991) with minor channel and lobes in comparison to the main channel zones (Kotlarczyk et al., 1991).

The Menilite Formation is regarded as a deep-sea deposit, i.e., laid down below shelf, as documented by mostly sedimentological analyses and other considerations (e.g., Ślączka \& Unrug, 1966; Książkiewicz, 1975; Unrug, 1980; Kotlarczyk et al., 2006), with some shallowing to upper bathyal-shelfal depths, as suggested by palaeontological data (Olszewska \& Malata, 2006; Malata \& Poprawa, 2006). Dziadzio et al. (2016) interpreted the Menilite Beds of the Silesian Nape in the Gorlice region as deposits of a shelfal setting. However, some authors considered a much shallower setting for the Menilite Formation in the Skole Nappe, in particular the Kliva Member and diatomites. Nalivkin $(1963,1967)$ regarded the Menilite Formation in general as lagoonal deposits, whereas Jarmołowicz-Szulc \& Jankowski (2011) determined sandstones of the Kliva Member in the outer part of the Skole Nappe as deposits of a shallow sea with hummocky cross stratification and diatomites contained therein as "semicontinental". According to Jankowski (2015, p. 43) diatomite horizons point to significant shallowing of the Menilite facies, even with possible emersion. Such ideas have been repeated several times (Jankowski \& Probulski, 2011; Jankowski et al., 2012a, 2015; Jankowski \& Leśniak, 2015). Jankowski \& Wysocka (2019) considered the Menilite Formation in the Skole Nappe as shelf deposits in general.

\section{Analytical methods}

Diatomite samples were disintegrated by freezing and thawing cycles in liquid nitrogen. Pieces of rock were initially examined under the stereomicroscope when representative pieces were handpicked for further analyses. Thin sections of individual fragments of conglomerate fraction and whole rock were used for microscopic observations and EDS analyses.

The fraction of $63-250 \mu \mathrm{m}$ was subjected to heavy mineral analyses. Heavy minerals were separated using sodium polytungstate of $2.9 \mathrm{~g} / \mathrm{cm}^{3}$ density as the heavy liquid and mounted in Canada balsam. For each sample, between 200 and 300 grains of transparent, non-micaceous minerals were counted according to the ribbon method. Rock and mineral grains were studied by means of the Scanning Electron Microscope HITACHI S-4700 in the Institute of Geological Sciences (Jagiellonian University) at Kraków. Qualitative composition of minerals was established using the EDS method. Since garnet is a provenance-sensitive mineral and is the dominant component of the heavy fraction in the material studied, it was chosen for chemical analyses. The chemical composition of 50 randomly chosen garnet grains was determined in carbon-coated polished sections with a wave-dispersion (WDS) electron microprobe using Cameca SX-100 at the Joint-Institute Analytical Complex for Minerals and Synthetic Substances at Warsaw University. The WDS analyses conditions were: $15 \mathrm{kV}$ accelerating voltage and $20 \mathrm{nA}$ beam current. Synthetic and natural mineral standards were used for analytical calibration: $\mathrm{Si}, \mathrm{Mg}, \mathrm{Ca}$ (diopside), $\mathrm{Al}$ (kyanite), $\mathrm{Cr}\left(\mathrm{Cr}_{2} \mathrm{O}_{3}\right), \mathrm{Ti}$ (rutile), $\mathrm{Fe}\left(\mathrm{Fe}_{2} \mathrm{O}_{3}\right)$, Mn (rhodonite). Garnet grains for analyses were chosen randomly. Garnets were checked for internal zoning. Due to the fact that the grains examined did not display chemical zoning, further chemical composition was examined in single spots located in the grain centres.

\section{Presentation and discussion of results}

The deposits studied contain detrital material of the sand to gravel fractions (Figs $4 \mathrm{~A}-\mathrm{H}, 5 \mathrm{~A}-\mathrm{H}$ ). The 

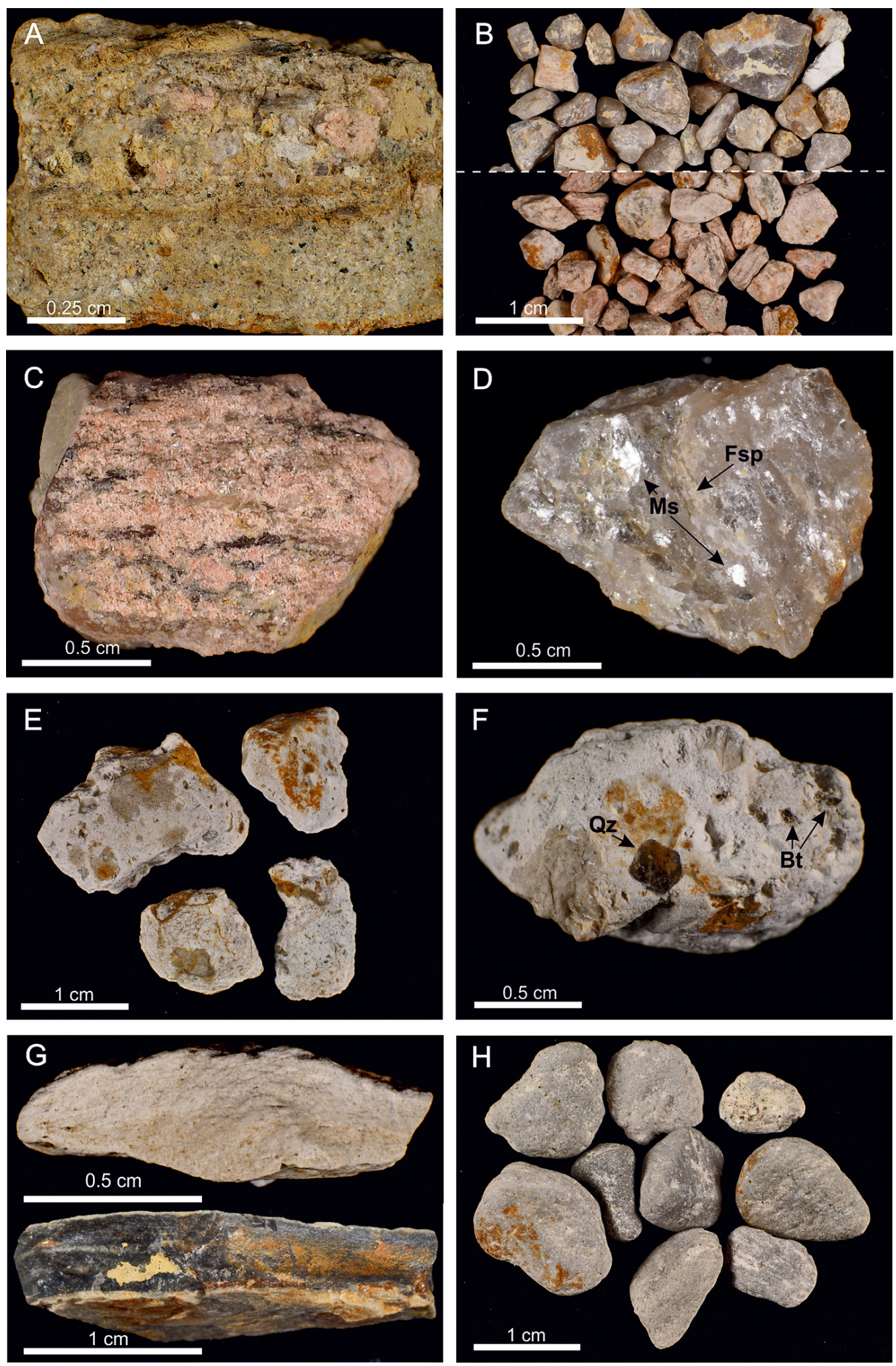

Fig. 4. Stereomicroscope images of gravel-fraction grains separated from the diatomitic sediment present in the Futoma Member of the Menilite Formation in the Nowy Borek section. A - Fragment of diatomite with numerous detritic grains represented by feldspars, quartz and rock fragments; B - Quartz grains (upper part) and rock fragments (lower part); C - Fragment of granite-gneiss consisting of pink feldspars and quartz streaks; D - Fragment of quartz with visible mica flakes; E - Fragments of pumice; F - Pumice fragment with phenocrysts of quartz and biotite; G - Fragments of white (upper part) and chocolate brown (lower part) cherts; $\mathbf{H}$ - Rounded grains of sandstones. Abbreviations: Bt - biotite; Fsp - feldspar; Ms - muscovite; Qz - quartz 
detritus is composed of individual minerals and rock fragments. Among mineral grains, glauconite, polycrystalline quartz and plagioclase and alkali feldspars occur. Among rock fragments, several lithologies may be distinguished.

1. Pieces of metamorphic rock (ranging from coarse sand fraction up to $15 \mathrm{~mm}$ in size), consisting of quartz or alkali and potassium pinkish feldspars intergrown with mica flakes (Fig. 4B-D) of biotite and muscovite composition. Macroscopically, these rock fragments look like granitic fragments (recognised as such by Kotlarczyk, 1985, 1991; Kotlarczyk \& Kaczmarska, 1987). However, a closer examination has revealed a preferred orientation of components, suggesting the metamorphic origin of the rocks (Fig. 4B, C). These rocks may be classified mostly as granite-gneisses or gneisses. Moreover, mica schist fragments are also present (Fig. 5B, D). The metamorphic pieces are angular to subangular and irregular in shape. They are the most abundant rock fragments in the deposits studied.

2. Volcanic rocks are represented by a) a light grey pumice (up to $15 \mathrm{~mm}$ in size), which contains isolated, macroscopically visible quartz and biotite crystals (Fig. 4E, F) and b) aphanitic volcanic rocks, which consist of feldspars currently totally replaced by clay minerals (Fig. 5E, F), which enable their proper classification.

3. Sedimentary rocks represented by chocolate brown and white cherts (Figs 4G, 5G) and rounded, grey-coloured sandstones, fragments of which measure up to $12 \mathrm{~mm}$ in size (Figs $4 \mathrm{H}$, $5 \mathrm{H})$. Some of the brown cherts are laminated, with lighter and darker laminae.

The heavy mineral fraction is dominated by garnet (65 per cent), which is accompanied by zircon (28 per cent). Rutile and epidote do not exceed 3 per cent each, while tourmaline, kyanite and staurolite comprise less than 1 per cent of the transparent heavy mineral group. The heavy minerals bear signs of advanced, variable corrosion traces ranging from superficial dissolution scars up to the skeletal form of grains, which suggests a chemically aggressive environment of burial.

The garnet population is dominated by almandine reaching up to $76 \mathrm{~mol} \%$. Rare grains are slightly enriched in grossular, spessartine or pyrope. Most of them do not exceed $30 \mathrm{~mol} \%$ (Table 1). Among the garnets studied, indicators of ultramafic origin, which should show $\mathrm{MgO}>\mathrm{FeO}$ (in wt \%), are absent. However, ultramaphic sources cannot be underestimated since they may contain garnet rich in $\mathrm{FeO}$ and $\mathrm{CaO}$ as well (e.g., Wan and Yeh, 1984; Dubińska, 1995; Gil, 2013). Additionally, some individual garnets show a $\mathrm{Cr}_{2} \mathrm{O}_{3}$ content that is slightly larger than 0.02 per cent, which suggests an ultramaphic origin (Tolosana-Delgado et al., 2018). Very rare garnets, characterised by $\mathrm{FeO}<10 \mathrm{MnO}$ (wt \%), may originate from felsic plutonic rocks, as recently suggested by Tolosana-Delgado et al. (2018). Other garnets may be interpreted as having been derived from metamorphic sources. Spots representing the other metamorphic garnets plot into fields denoting their provenance mainly from highto medium-grade metasediments (Fig. 6 I). Internal zoning in single grains was not detected. However, the detrital garnet in the sand fraction represents mostly pieces of larger garnets. Therefore, it cannot be excluded that the primary garnets were zonal, although it is not possible to prove this. The presence of metamorphic minerals, e.g., kyanite and staurolite, supports the metamorphic origin of the garnet population. They may have originated mainly from gneisses and amphibolites that were altered under conditions of the amphibolite facies and transitional to the granulite facies. Garnet from high-pressure granulites and eclogites seems to be present in smaller amounts than the other types (Fig. 6 II, III).

The heavy mineral assemblage from the Nowy Borek section differs from those recognised in sandstones of the Menilite Formation as well in the older Ropianka Formation (Campanian-Paleocene), which were supplied from the northern foreland of the Skole Basin (e.g., Salata \& Uchman, 2013). These formations are characterised by large quantities of zircon, tourmaline, rutile, kyanite and staurolite with garnet, which do not exceed 27 per cent (e.g., Salata \& Uchman, 2013). Conversely, the detrital components of the Futoma Member at Nowy Borek are dominated by garnet with a subordinate contribution of other minerals. The contrasting composition of the heavy mineral assemblages in these formations may suggest the provenance of sediments of Borek Nowy from other sources than the Menilite and Ropianka formations. Detrital material of the Ropianka and Menilite formations represents primary and secondary sources, which could be located in the northern margin of the Skole Basin, partly within the basin or in the basin foreland located to the northwest, as indicated by palaeotransport directions (Bromowicz, 1974, 1986; Salata \& Uchman, 2012, 2013; Salata, 2013a, b, 2014). Metamorphic source rocks for these formations seem to be similar to those outcropping at present in the crystalline basement of the Brunovistulicum or crystalline domains of the Bohemian Massif (Salata, 2013a, b).

The distinctively different heavy mineral assemblages in the Nowy Borek section may have resulted from erosion of a local metamorphic source that 

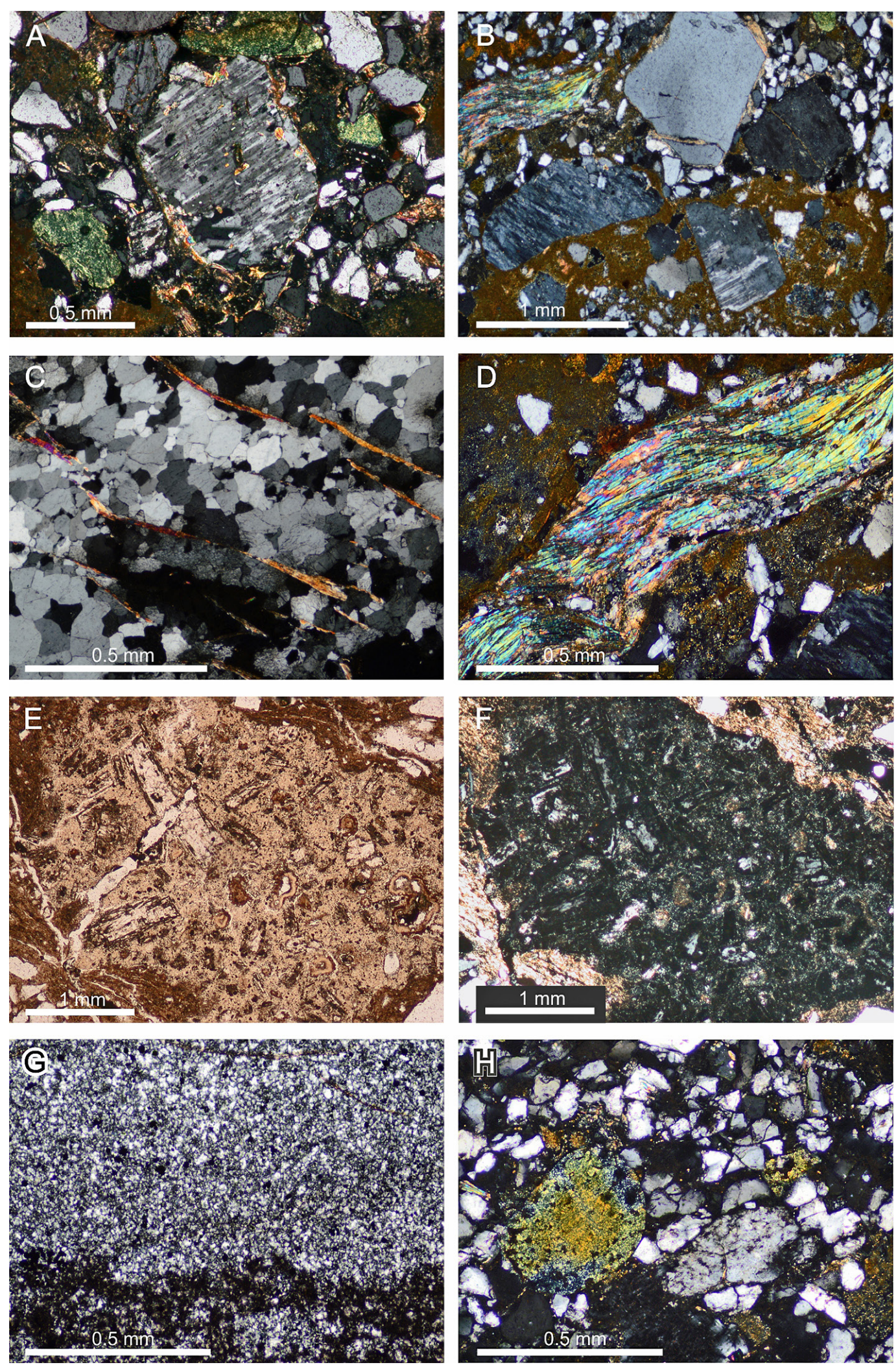

Fig. 5. Microscopic images of grains present in the diatomite in the Nowy Borek section. A - Rock fragments, feldspars, quartz and glauconite grains (XPL); B - Quartz, feldspar and mica schist fragments (XPL); C - Quartz with mica flakes showing parallel texture (XPL); D - Clast of a metamorphic schist (XPL); E, F - Clast of aphanitic rock consisting of feldspars replaced by clay minerals (E - PPL, F - XPL); G - Chert (XPL); H - Sandstone grain consisting of quartz, feldspar and glauconite (XPL). Abbreviations: PPL - Plane Polarised Light; XPL - crossed nicols 
was rich in garnet. The angular character of many clasts, especially those which contain feldspar crystals, indicates a rather proximal location of the source area and its primary character. However, the garnet composition in the Nowy Borek section, very similar to garnet from the Ropianka and Menilite formations, suggests the same lithology of source rocks and metamorphic conditions (Fig. 6). Therefore, it should be taken into account that the local source which supplied the Nowy Borek section could have been a kind of a fragment of the Brunovistulicum metamorphic structures.

The proposed provenance of the detritus from the Nowy Borek section corresponds well with current knowledge of exotic pebbles found in older deposits of the Skole Nappe. Gneisses of similar composition to those from the Nowy Borek section have also been found in the Ropianka Formation at Wola Rafałowska (Łapcik et al., 2016) and at Husów in the central part of the village (Wdowiarz, 1949) and at Patria hill (unpublished data), all located to the north and northeast of the Nowy Borek section. Peb- bles of metamorphic origin, such as gneisses, marbles, quartzites and hornfelses, as well igneous pebbles of granites, andesitic-basalts and others, were recognised in Campanian-Maastrichtian deposits of the Ustrzyki Dolne area (see Żytko \& Zimnal, 1997). This suggests that the metamorphic source in question could have been active already since the Late Cretaceous and lasted at least until the Oligocene.

Along with the local metamorphic source, grey sandstones and white and chocolate brown chertswere eroded. The chocolate brown cherts are typical of the Menilite Formation (and the Kotów Chert Member in particular), while white cherts may occur in diatomite horizons. However, a source for sandstone pebbles is difficult to determine since this kind of sandstone may occur in many formations of the Skole Nappe or in the foreland. At least the cherts prove that the lower part of the Menilite Formation was locally eroded during sedimentation of the Futoma Member, even if this time interval was considered as the most quiescent in the sense of diastrophic processes (Kotlarczyk \& Leśniak, 1990).

Table 1. Representative analyses of garnet from the Borek Nowy section

\begin{tabular}{|c|c|c|c|c|c|c|c|c|c|c|c|c|}
\hline Formula & 1 & 2 & 3 & 4 & 5 & 6 & 7 & 8 & 9 & 10 & 11 & 12 \\
\hline $\mathrm{SiO}_{2}[\mathrm{wt} \%]$ & 37.18 & 38.30 & 36.77 & 38.13 & 37.21 & 36.98 & 36.86 & 37.88 & 36.78 & 38.87 & 38.19 & 38.05 \\
\hline $\mathrm{Al}_{2} \mathrm{O}_{3}$ & 21.06 & 21.80 & 19.75 & 21.65 & 20.85 & 20.64 & 20.90 & 21.29 & 19.70 & 22.18 & 21.63 & 21.35 \\
\hline $\mathrm{TiO}_{2}$ & 0.02 & 0.00 & 0.02 & 0.04 & 0.06 & 0.06 & 0.05 & 0.02 & 0.18 & 0.05 & 0.04 & 0.11 \\
\hline $\mathrm{Cr}_{2} \mathrm{O}_{3}$ & 0.01 & 0.03 & 0.00 & 0.04 & 0.01 & 0.02 & 0.01 & 0.14 & 0.00 & 0.10 & 0.16 & 0.00 \\
\hline $\mathrm{Fe}_{2} \mathrm{O}_{3}{ }^{*}$ & 0.33 & 0.40 & 2.12 & 0.14 & 0.84 & 0.41 & 0.56 & 0.52 & 2.12 & 0.16 & 0.51 & 0.75 \\
\hline $\mathrm{FeO}$ & 34.45 & 29.81 & 17.28 & 29.55 & 25.71 & 29.87 & 33.60 & 29.60 & 17.67 & 25.74 & 29.36 & 25.43 \\
\hline $\mathrm{MnO}$ & 1.00 & 0.30 & 11.63 & 0.55 & 3.27 & 2.60 & 2.42 & 1.23 & 10.43 & 0.38 & 0.48 & 0.39 \\
\hline $\mathrm{MgO}$ & 3.79 & 8.22 & 0.06 & 7.45 & 1.25 & 1.29 & 2.02 & 6.04 & 0.05 & 10.57 & 7.93 & 4.46 \\
\hline $\mathrm{CaO}$ & 2.12 & 1.34 & 12.62 & 1.97 & 10.99 & 7.50 & 4.07 & 3.34 & 13.27 & 1.57 & 1.95 & 9.75 \\
\hline Total $_{0}$ & 99.97 & 100.20 & 100.24 & 99.51 & 100.19 & 99.38 & 100.50 & 100.05 & 100.20 & 99.61 & 100.26 & 100.29 \\
\hline \multicolumn{13}{|c|}{ Cations calculated per 12 oxygen atoms } \\
\hline $\mathrm{Si}$ & 2.982 & 2.974 & 2.966 & 2.987 & 2.972 & 2.995 & 2.970 & 2.980 & 2.963 & 2.978 & 2.969 & 2.974 \\
\hline $\mathrm{Al}$ & 1.993 & 1.998 & 1.888 & 1.999 & 1.967 & 1.972 & 1.988 & 1.976 & 1.881 & 2.003 & 1.985 & 1.970 \\
\hline $\mathrm{Ti}$ & 0.001 & 0.000 & 0.001 & 0.002 & 0.004 & 0.004 & 0.003 & 0.001 & 0.011 & 0.003 & 0.002 & 0.007 \\
\hline $\mathrm{Cr}$ & 0.001 & 0.002 & 0.000 & 0.002 & 0.001 & 0.001 & 0.001 & 0.009 & 0.000 & 0.006 & 0.010 & 0.000 \\
\hline $\mathrm{Fe}^{3+}$ & 0.020 & 0.024 & 0.128 & 0.008 & 0.051 & 0.025 & 0.034 & & 0.128 & 0.009 & 0.030 & 0.044 \\
\hline $\mathrm{Fe}^{2+}$ & 2.311 & 1.936 & 1.165 & 1.936 & 1.717 & 2.023 & 2.265 & 1.947 & 1.190 & 1.649 & 1.909 & 1.662 \\
\hline $\mathrm{Mn}$ & 0.068 & 0.019 & 0.794 & 0.036 & 0.221 & 0.178 & 0.165 & 0.082 & 0.711 & 0.025 & 0.031 & 0.026 \\
\hline $\mathrm{Mg}$ & 0.454 & 0.951 & 0.007 & 0.870 & 0.148 & 0.156 & 0.242 & 0.709 & 0.006 & 1.208 & 0.919 & 0.519 \\
\hline $\mathrm{Ca}$ & 0.182 & 0.111 & 1.090 & 0.165 & 0.941 & 0.651 & 0.352 & 0.281 & 1.146 & 0.129 & 0.163 & 0.816 \\
\hline Total $_{c a}$ & 8.012 & 8.015 & 8.040 & 8.007 & 8.022 & 8.005 & 8.020 & 8.015 & 8.036 & 8.009 & 8.018 & 8.018 \\
\hline \multicolumn{13}{|c|}{ Calculated garnet end-members [mol \%] } \\
\hline Almandine & 76.4 & 63.6 & 36.2 & 64.1 & 55.9 & 67.1 & 74.4 & 64.0 & 37.1 & 54.3 & 62.5 & 54.2 \\
\hline Andradite & 1.0 & 1.2 & 6.5 & 0.4 & 2.5 & 1.3 & 1.7 & 1.5 & 6.5 & 0.5 & 1.5 & 2.2 \\
\hline Grossular & 5.1 & 2.4 & 30.3 & 5.0 & 29.1 & 20.4 & 10.1 & 7.5 & 32.2 & 3.6 & 3.5 & 25.2 \\
\hline Pyrope & 15.2 & 32.0 & 0.2 & 29.1 & 5.0 & 5.2 & 8.2 & 23.8 & 0.2 & 40.6 & 31.0 & 17.5 \\
\hline Spessartine & 2.3 & 0.7 & 26.8 & 1.2 & 7.4 & 6.0 & 5.6 & 2.7 & 24.0 & 0.8 & 1.1 & 0.9 \\
\hline Uvarovite & 0.0 & 0.1 & 0.0 & 0.1 & 0.0 & 0.1 & 0.0 & 0.4 & 0.0 & 0.3 & 0.5 & 0.0 \\
\hline
\end{tabular}

*The content of $\mathrm{FeO} / \mathrm{Fe}_{2} \mathrm{O}_{3}$ calculated basing on charge balance. 
The volcanic rock fragments may correspond to Paleogene tuffite horizons, which are known from the Skole Nappe, including the diatomite horizons, as well as from the neighbouring Subsilesian Unit and the Silesian Nappe (e.g., Sikora et al., 1959; Koszarski \& Wieser, 1960; Kotlarczyk, 1966, 1988; Koszarski \& Koszarski, 1985; Rajchel, 1990; Cieszkowski et al., 2006; Kotlarczyk et al., 2006) and also to some volcanic rock pebbles from the lower part of the Menilite Formation in the Skole Nappe (e.g., Salata, Uchman and Dudek, 2014, unpublished data). The volcanic rock occurrences may be related to andesitic and rhyolitic volcanism dating back to the Eocene/Oligocene and occurring on the Carnian Plate (or the Pannonian micro-continent). The volcanic events are documented by numerous
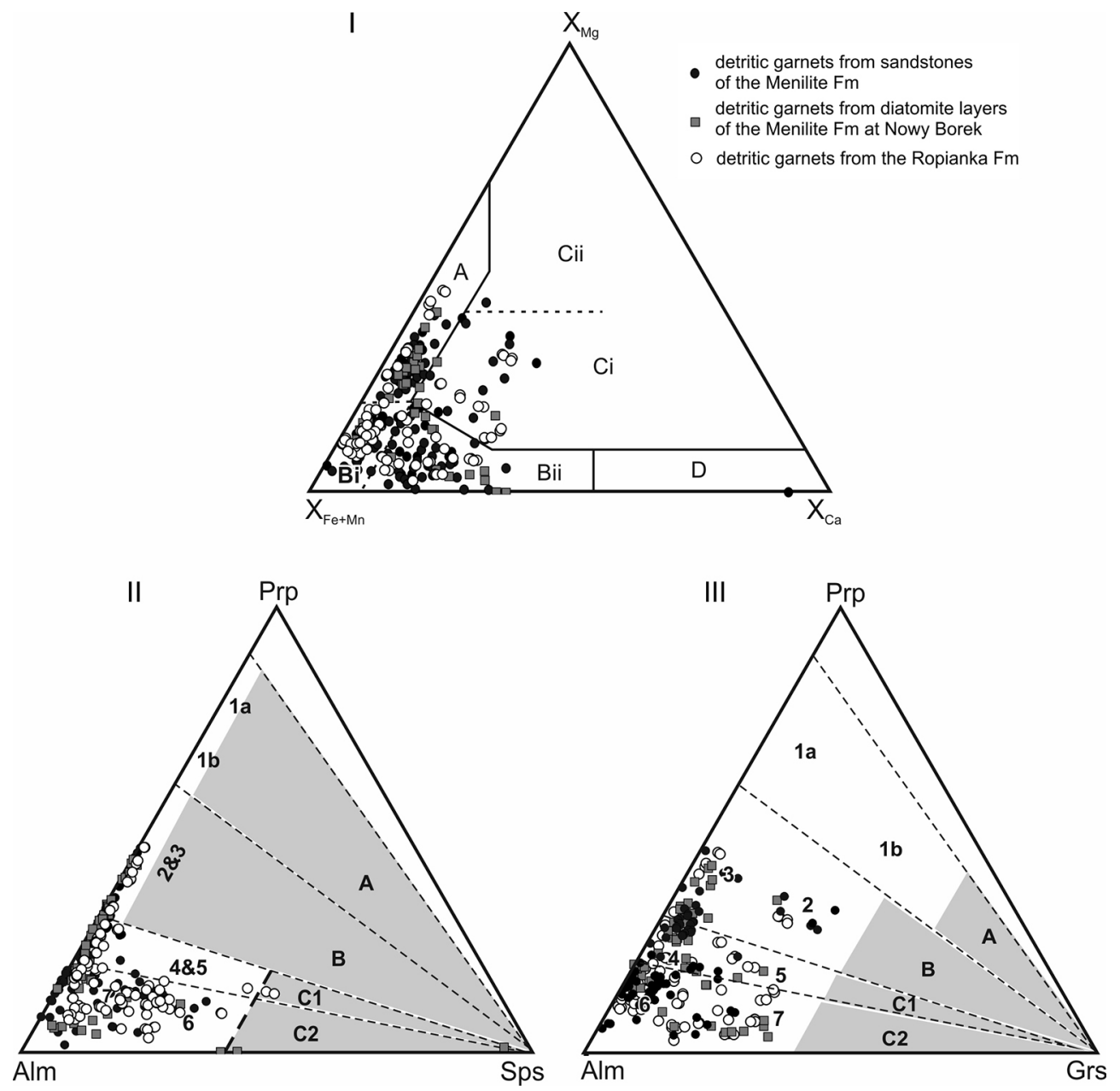

Fig. 6. Provenance diagram of garnets in the Nowy Borek section compared to garnets from the Ropianka and Menilite formations. Diagram I: field A - garnets mainly from high-grade, granulite-facies metasediments or charnockites, but also from intermediate-acidic igneous rocks sourced from deep in the crust: field B - garnets from amphibolite facies metasediment, where Bi field suggests derivation from intermediate-acidic igneous rocks; field C - garnets mainly from high-grade metabasic rocks, where field Cii implies sourcing from ultramafics such as pyroxenites and peridotites; field D - garnets generally from metasomatic rocks such as skarns, from very low-grade metabasic rocks, or from ultra-high temperature metamorphosed calc-silicate granulites (Mange \& Morton, 2007). Diagrams II and III: composition of garnet in the light of metamorphic conditions. Field A - HP/UHP conditions; field B - granulite and eclogite facies conditions; field C1 - transitional field of high amphibolite to granulite facies conditions; field C2 - amphibolite facies conditions (this field includes also garnet from blue schists, skarns, serpentinites, igneous rocks etc.). Source rocks of individual garnets: 1a - garnet from UHP eclogites, garnet-peridotites and kimberlites; $1 \mathrm{~b}$ - garnet from UHP eclogites; 2 - garnet from HP eclogites and HP mafic granulites; 3 - garnet from HP felsic and intermediate granulites; 4 - garnet from gneisses metamorphosed under P-T conditions transitional to granulite and amphibolite facies; 5 - garnet from amphibolites metamorphosed under P-T conditions transitional to granulite and amphibolite facies; 6 - garnet from gneisses metamorphosed under amphibolite facies conditions; 7 - garnet from amphibolites metamorphosed under amphibolite facies conditions (see Aubrecht et al., 2009 and references therein). Garnet data for the Ropianka and Menilite formations after Salata (2013a, b) 
tuffite (bentonite) horizons that intercalate Flysch Carpathians strata between the Campanian and the Lower Miocene (e.g., Van Couvering et al., 1981, and references therein). Based on zircons, the age of the tuffite layers within the Krosno Formation in the Skole Nappe was determined as no younger than Late Oligocene/Early Miocene (Van Couvering et al., 1981), but biostratigraphic data prove their occurrence also in the Early Miocene Krosno Formation of the Skole Nappe (Kotlarczyk et al., 2006).

\section{Conclusions}

The coarse-grained detrital material present in the Futoma Member of the Menilite Formation in the Nowy Borek section contains a variety of metamorphic, volcanic and sedimentary rocks deposited from primary and secondary sources. Commonest are debris of metamorphic rocks, mainly granite-gneisses or gneisses and fewer mica schists. This conclusion contradicts previous opinions about a granitic provenance of the clasts. The metamorphic origin of the clasts is also confirmed by the chemical composition of garnets. The clasts were transported from a local source situated close to or within the Skole Basin. The results show that some source of crystalline, mainly metamorphic, rocks existing in the Campanian-Paleocene was still active during the Oligocene and that older rocks of the Skole Nappe successions were simultaneously eroded. It is proof of probably the youngest activity of a crystalline source in the Skole Basin. The volcanic rocks are related to volcanic activity that was widespread in the Carpathian region during the Paleogene, while cherts were most probably eroded from the older part of the Menilite Formation.

\section{Acknowledgements}

This work was supported by scientific project number 2013/09/B/ST10/00591, financed by the National Science Centre. Janusz Kotlarczyk (19312017) guided one of us (A.U.) to the outcrop studied in 2011 and pointed out the importance of the present topic.

\section{References}

Aubrecht, R., Meres, Š., Sykora, M. \& Mikuš, T., 2009. Provenance of the detrital garnets and spinels from the Albian sediments of the Czorsztyn Unit (Pieniny
Klippen Belt, Western Carpathians, Slovakia). Geologica Carpathica 60, 463-483.

Bromowicz J., 1974. Facial variability and lithological character of Inoceramian Beds of the Skole Nappe between Rzeszów and Przemyśl. Prace Geologiczne Polskiej Akademii Nauk 84, 1-81 (in Polish with English summary).

Bromowicz, J., 1986. Petrographic differentiation of source areas of Ropianka Beds east of Dunajec River (Outer Carpathians, Poland). Annales Societatis Geologorum Poloniae 56, 253-276 (in Polish with English summary).

Bukowy, S., 1957. Remarks on the sedimentation of the Babica Clays. Rocznik Polskiego Towarzystwa Geologicznego 26, 147-155 (in Polish with English summary).

Cieszkowski, M., Środon, J., Waśkowska-Oliwa, A. \& Leśniak, T., 2006. Bentonitized tuffites in the Lower Eocene deposits of the Subsilesian Unit (Western Outer Carpathians, Poland), lithology, stratigraphic position and mineral composition. Annales Societatis Geologorum Poloniae 76, 197-214.

Dubińska, E., 1995. Rodingites of the eastern part of the Jordanów-Gogołów serpentinite massif, Lower Silesia, Poland. Canadian Mineralogist 33, 585-608

Dziadzio, P.S., Matyasik, I., Garecka, M. \& Szydło, A., 2016. Lower Oligocene Menilite Beds, Polish Outer Carpathians, supposed deep-sea flysch locally reinterpreted as shelfal, based on new sedimentological, micropalaeontological and organic-geochemical data. Instytut Nafty i Gazu - Państwowy Instytut Badawczy, Kraków, 120 pp.

Gągała, Ł., Vergés, J., Saura, E., Malata T., Ringenbach, J.C., Werner, P. \& Krzywiec, P., 2012. Architecture and orogenic evolution of the north-eastern Outer Carpathians from cross-section balancing and forward modelling. Tectonophysics 532-535, 223-241.

Gil, G., 2013. Petrographic and microprobe study of nephrites from Lower Silesia (SW Poland). Geological Quarterly 57, 395-404.

Grzebyk, J. \& Leszczyński, S., 2006. New data on heavy minerals from the Upper Cretaceous-Paleogene flysch of the Beskid Śląski Mts. (Polish Carpathians). Geological Quarterly 50, 265-280.

Jankowski, L., 2015. Nowe spojrzenie na budowe geologiczna Karpat - ujęcie dyskusyjne. Instytut Nafty i Gazu Państwowy Instytut Badawczy, Kraków, 154 pp. (in Polish).

Jankowski, L. \& Leśniak, G., 2015. Wojkowa - warstwy menilitowe [Łodyna - Menilite Beds]. [In]: M. Ciechanowska, W. Urzędowska, J. Jaworski, J. Lubaś \& P. Such (Eds): Wybrane aspekty system naftowego a nowe spojrzenie na geologie Karpat. Instytut Nafty i Gazu Państwowy Instytut Badawczy, Kraków, 132-138.

Jankowski, L. \& Probulski, J., 2011. Tectonic and basinal evolution of the Outer Carpathians based on example of geological structure of the Grabownica, Strachocina and Łodyna hydrocarbon deposits. Geologia 37, 555-583.

Jankowski, L. \& Wysocka, A., 2019. Occurrence of clastic injectites in the Oligocene strata of the Carpathians and their significance in unravelling the Paleogene and Neogene evolution of the Carpathian orogeny 
(Poland, Ukraine and Romania). Geological Quarterly 63, 106-125.

Jankowski, L., Kopciowski, R. \& Ryłko, W., 2012a. The state of knowledge of geological structures of the Outer Carpathians between Biała and Risca rivers - discussion. Biuletyn Państwowego Instytutu Geologicznego 449, 203-216.

Jankowski, L., Kopciowski, R., Ryłko, W., Danysh, V., Tsarnenko, P.N. \& Hnylko, O., 2012b. Lithostratigraphic correlation of the Outer Carpathian borderlands of Poland, Ukraine, Slovakia and Romania. Biuletyn Państwowego Instytutu Geologicznego 449, 87-908.

Jankowski, L., Leśniak, G. \& Matyasik, I., 2015. Łodyna warstwy menilitowe [Łodyna - Menilite Beds]. [In]: M. Ciechanowska, W. Urzędowska, J. Jaworski, J. Lubaś \& P. Such (Eds): Wybrane aspekty system naftowego a nowe spojrzenie na geologie Karpat. Instytut Nafty i Gazu - Państwowy Instytut Badawczy, Kraków, 43-53.

Jarmołowicz-Szulc, K. \& Jankowski, L., 2011. Geochemical analysis and genetic correlation for bitumens and rocks of black shale type in the Outer Carpathians tectonic units in southeastern Poland and the adjacent territory. Biuletyn Państwowego Instytutu Geologicznego 444, 73-98.

Koszarski, L. \& Koszarski, A., 1985. Siedliska at Wisłok river Menilite beds and Eocene series, in profiles of central zone of the Skole unit east of Wisłok river. [In:] L. Koszarski (Ed.): Geology of the Middle Carpathians and the Carpathian Foredeep. Guide to excursion 3. Carpatho-Balkan Geological Association XIII Congress. Kraków, 100-101.

Koszarski, L. \& Wieser, T., 1960. New tuff horizons in older Palaeogene of Flysch Carpathians. Kwartalnik Geologiczny 4, 749-770.

Kotlarczyk, J., 1966. Poziom diatomitowy warstw krośnieńskich na tle budowy geologicznej jednostki skolskiej w Karpatach polskich [Diatomite horizons of the Krosno beds in the Skole Nappe, Polish Carpathians.] Studia Geologica Polonica 19, 129 pp.

Kotlarczyk, J., 1976. Przyczynki do wyjaśnienia genezy piaskowców kliwskich w Karpatach Polskich. Sprawozdania z Posiedzeń Komisji Naukowej PAN, Kraków, 19, 185-187 (in Polish).

Kotlarczyk, J., 1982. The role of diatoms in sedimentation and biostratigraphy of Polish Flysch Carpathians. Acta Geologica Academiae Scientiarum Hungaricae 25, 9-21.

Kotlarczyk, J., 1985. An outline of the stratigraphy if marginal tectonic units of the Carpathian Orogen in the Rzeszów-Przemyśl area. [In:] J. Kotlarczyk (Ed.): Geotraverse Kraków-Baranów-Rzeszów-Przemyśl-Ustrzyki Dolne-Komańcza-Dukla. Guide to excursion 4. Carpatho-Balkan Geological Association XIII Congress. Kraków, 39-63.

Kotlarczyk, J., 1988. Zarys stratygrafii brzeżnych jednostek tektonicznych orogenu karpackiego. [In:] J. Kotlarczyk et al. (Eds): Przewodnik LIX Zjazdu Polskiego Towarzystwa Geologicznego, Karpaty Przemyskie, Kraków, 31-62 (in Polish).
Kotlarczyk, J., 1991. Problematyka basenu fliszowego w paleogenie. [In:] J. Kotlarczyk (Ed.): Paleontologia a batymetria. Wydawnictwo AGH, Kraków, pp. 51-64.

Kotlarczyk, J. \& Kaczmarska, I., 1987. Two diatom horizons in the Oligocene and Lower Miocene of the Polish Outer Carpathians. Rocznik Polskiego Towarzystwa Geologicznego 57, 143-188.

Kotlarczyk, J. \& Leśniak, T., 1990. Lower Part of the Menilite Formation and Related Futoma Diatomite Member in the Skole Unit of the Polish Carpathians. Wydawnictwo Akademii Górniczo-Hutniczej, Kraków (in Polish with English summary).

Kotlarczyk, J. \& Śliwowa, M., 1963. On knowledge of the productive Carboniferous formations in the substratum of the eastern part of the Polish Carpathians. Przeglad Geologiczny 11, 268-272 (in Polish with English summary).

Kotlarczyk, J. \& Uchman, A., 2012. Integrated ichnological and ichthyological analysis of oxygenation changes in the Menilite Formation during Oligocene, Skole and Subsilesian nappes, Polish Carpathians. Palaeogeography Palaeoclimatology Palaeoecology 331-332, 104-118.

Kotlarczyk, J., Krawczyk, A.J. \& Leśniak, T., 1991. Poziom diatomitów z Futomy w polskich Karpatach fliszowych [The Futoma diatomite horizon in the Polish Flysch Carpathians]. Prace Wtasne, Akademia Górniczo-Hutnicza, Kraków, 28, 1-231.

Kotlarczyk, J., Jerzmańska, A., Świdnicka, E. \& Wiszniowska, T., 2006. A framework of ichthyofaunal ecostratigraphy of the Oligocene-Early Miocene strata of the Polish Outer Carpathian basin. Annales Societatis Geologorum Poloniae 76, 1-111.

Książkiewicz, M. (Ed.), 1962. Geological Atlas of Poland. 13 - Cretaceous and Early Tertiary in the Polish External Carpathians. Instytut Geologiczny, Warszawa.

Książkiewicz, M., 1975. Bathymetry of the Carpathian Flysch Basin. Acta Geologica Polonica 25, 309-367.

Łapcik, P., Kowal-Kasprzyk, J. \& Uchman, A., 2016. Deepsea mass-flow sediments and their exotic blocks from the Ropianka Formation (Campanian-Paleocene) in the Skole Nappe: a case study of the Wola Rafałowska section (SE Poland). Geological Quarterly 60, 301-319.

Malata, T., 1996. An analysis of formal lithostratigraphic divisions and a proposition of the subdivision of the Skole Unit of the Polish Flysch Carpathians. Przeglad Geologiczny 44, 509-514.

Malata, T., 2006. Warstwy menilitowe w kamieniołomie w Tarnawce [Menilite Beds in Tarnawka]. [In:] T. Słomka, M. Doktor, A. Joniec \& A. Kicińska-Świderska (Eds): Katalog obiektów geoturystycznych w Polsce. Wydawnictwo Akademii Górniczo-Hutniczej, Kraków, 158-159.

Malata, T. \& Poprawa, P., 2006. Evolution of the Skole Subbasin. [In:] N. Oszczypko, A. Uchman \& E. Malata (Eds): Rozwój Paleotektoniczny Basenów Karpat Zewnętrznych i Pienińskiego Pasa Skatkowego. Instytut Nauk Geologicznych Uniwersytetu Jagiellońskiego, Kraków, 103-110.

Mange, M.A. \& Morton, A.C., 2007. Geochemistry of heavy minerals. [In:] M.A. Mange \& D.T. Wright 
(Eds): Heavy Minerals in Use. Developments in Sedimentology 58, 345-391.

Nalivkin, D.W., 1963. Flysch - continental deposit. Asociația Geologică Carpato-Balcanică, Congresul, București 3, 67-73 [in Russian].

Naliwkin, D.W., 1967. Fauna in the flysch area of the Polish Carpathian Mts. Kwartalnik Geologiczny 11, 866-876.

Olszewska, B. \& Malata, E., 2006. Palaeonvironmental and palaeobatymetric analysis of microfossils assemblages of the Polish Outer Carpathians. [In:] N. Oszczypko, A. Uchman \& E. Malata (Eds): Rozwój Paleotektoniczny Basenów Karpat Zewnętrznych i Pienińskiego Pasa Skatkowego. Instytut Nauk Geologicznych Uniwersytetu Jagiellońskiego, Kraków, 61-84.

Rajchel, J., 1990. Lithostratigraphy of the Upper Paleocene and Eocene sediments from the Skole Unit. Zeszyty Naukowe AGH, Geologia 48, 1-113 (in Polish with English summary).

Rajchel, J. \& Myszkowska, J., 1998. Exotic clasts of organodetritic algal limestones from lithosomes of the Babica Clay, Skole Unit (Outer Flysch Carpathians, Poland). Annales Societatis Geologorum Poloniae 68, 225-235.

Salata, D., 2013a. Garnet provenance in mixed first-cycle and poly-cycle heavy mineral assemblages of the Ropianka and Menilite formations (Skole Nappe, Polish Flysch Carpathians): constraints from chemical composition and grain morphology. Annales Societatis Geologorum Poloniae 83, 161-177.

Salata, D., 2013b. Source rocks for heavy minerals in lower part of Menilite Formation of Skole Nappe (Polish Flysch Carpathians), based on study of detrital garnet and tourmaline. Annales Societatis Geologorum Poloniae 83, 1-17.

Salata, D., 2014. Detrital tourmaline as indicator of its source rocks lithology: example from the Ropianka and Menilite formations (Skole Nappe, Polish Flysch Carpathians). Geological Quarterly 58, 19-30.

Salata, D. \& Uchman, A., 2012. Heavy minerals from the Oligocene sandstones of the Menilite Formation of the Skole Nappe, SE Poland: a tool for provenance specification. Geological Quarterly 56, 803-820.

Salata, D. \& Uchman, A., 2013. Conventional and high-resolution heavy mineral analyses applied to flysch sediments: comparative provenance studies of the Ropianka (Upper Cretaceous-Palaeocene) and Menilite (Oligocene) formations (Skole Nappe, Polish Carpathians). Geological Quarterly 57, 649-664.
Sikora, W., Wieser, T., Żgiet, J. \& Żytko, K., 1959. Tuff horizons in the Menilite-Krosno series of the Flysch Carpathians. Bulletin de l'Academie Polonaise des Sciences, Série des Sciences Chimiques, Géologiques et Géographiques 7, 497-503.

Skulich, J., 1986. Badania magmowych skał egzotycznych we wschodnich Karpatach fliszowych. Kwartalnik Geologiczny 30, 135-136 (in Polish).

Szczurowska, J., 1970. Minerały ciężkie w otworze wiertniczym Przysietnica IG-1. Kwartalnik Geologiczny 14, 915-916 (in Polish).

Szczurowska, J., 1971. Wstępne badania minerałów ciężkich serii menilitowo-krośnieńskiej w odwiercie Jasień IG-1. Kwartalnik Geologiczny 15, 732 (in Polish).

Szczurowska, J., 1973. Minerały ciężkie końcowego odcinka wiercenia Jasień IG 1 w Bieszczadach (cz. II). Kwartalnik Geologiczny 17, 643-644 (in Polish).

Ślączka, A. \& Unrug, R., 1966. Sedimentary structures and petrology of some sandstone members of the Menilite Beds, Carpathians). Rocznik Polskiego Towarzystwa Geologicznego 36, 155-180.

Tolosana-Delgado, R., von Eynatten, H., Krippner, A. \& Meinhold, G., 2018. A multivariate discrimination scheme of detrital garnet chemistry for use in sedimentary provenance analysis, Sedimentary Geology $375,14-26$.

Unrug, R., 1980. Ancient contourites in the Menilite Beds (Oligocene) of the Carpathian Flysch, Poland. Rocznik Polskiego Towarzystwa Geologicznego 50, 175-182.

Van Couvering, J.A., Aubry M.-P., Berggren, W.A., Bujak, C.W., Naeser C.W. \& Wieser, T., 1981. The Terminal Eocene Event and the Polish connection. Palaeogeography Palaeoclimatology Palaeoecology 36, 321-362.

Wan H.-M. \& Yeh C.-L. 1984. Uvarovite and grossular from the Fengtien nephrite deposits, eastern Taiwan. Mineralogical Magazine 48, 31-37.

Wdowiarz, S., 1949. Structure géologique des Carpates marginales au sud-est de Rzeszów. Biuletyn Państwowego Instytutu Geologicznego 11, 1-51 (in Polish with French summary).

Żytko, K. \& Zimnal., Z., 1997. Objaśnienia do szczegótowej mapy geologicznej Polski 1:50 000, arkusz Ustrzyki Dolne. Państwowy Instytut Geologiczny, Warszawa, 44 pp (in Polish).

Manuscript received: 15 May 2019 Revision accepted: 22 July 2019 